\title{
Human interference and avifaunal diversity of two wetlands of Jalpaiguri, West Bengal, India
}

\author{
Tanmay Datta \\ Department of Zoology, Ananda Chandra College, Jalpaiguri, West Bengal 735101, India \\ Email: tdatta1963@gmail.com
}

Date of publication (online): 26 December 2011 Date of publication (print): 26 December 2011 ISSN 0974-7907 (online) | 0974-7893 (print)

Editor: Rajiv S. Kalsi

\section{Manuscript details:}

Ms \# 02739

Received 28 March 2011

Final received 18 October 2011

Finally accepted 28 October 2011

Citation: Datta, T. (2011). Human interference and avifaunal diversity of two wetlands of Jalpaiguri, West Bengal, India. Journal of Threatened Taxa 3(12): 2253-2262.

Copyright: (C) Tanmay Datta 2011. Creative Commons Attribution 3.0 Unported License. JoTT allows unrestricted use of this article in any medium for non-profit purposes, reproduction and distribution by providing adequate credit to the authors and the source of publication.

Author Details: Associate Professor in Zoology of Ananda Chandra College, Jalpaiguri, West Bengal. Presently working on wetland ecology and biodiversity; specially on diversity of zooplanktons, fishes and water birds.

Acknowledgements: This study was financially supported by the University Grants Commission, India. I am thankful to the Department of Zoology, Ananda Chandra College, for providing all sorts of infrastructural support. I also thank Dr. Amal Kumar Patra, Mr. Santanu Ghosh Dastidar and Mr. Suman Senupta who helped me in various ways during field studies and laboratory works.
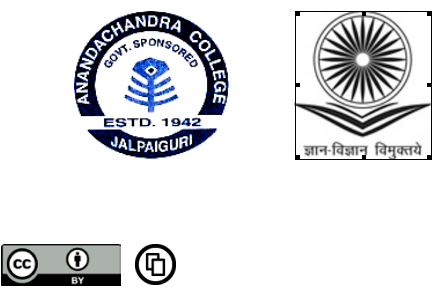

OPEN ACCESS | FREE DOWNLOAD
Abstract: Avifaunal diversity and abundance were studied in two wetlands of Jalpaiguri District, West Bengal, India, in relation to eight wetland characteristics supposedly directly or indirectly affected by human activities. Although the climatic and geophysical conditions of both the wetlands are almost similar, a total of 80 bird species were recorded from one wetland and the other supported only 42 species. The relationship between habitat characteristics and community structure varied throughout the year, suggesting that the birds respond differently to one or other habitat characteristic depending on the season. Larger wetland size supported higher bird diversity and abundance as far as resident and local migrants are concerned. Winter migrant density and diversity, however, reached higher values in structurally more heterogeneous wetlands having fewer submerged aquatic vegetation. All these habitat characteristics become highly influenced by intense agricultural practices in the wetland with fewer bird diversity and density.

Keywords: Habitat heterogeneity, human interference, Jalpaiguri, submerged aquatic vegetation, waterbirds, wetlands.

\section{INTRODUCTION}

Although wetlands are one of the most productive ecosystems and most severely affected habitats next to tropical forests, they are being neglected in densely populated countries like India. In the last century, over $50 \%$ of wetlands in the world have been lost, and the remaining wetlands have been degraded to different degrees because of the adverse influence of human activities (Fraser \& Keddy 2005).

Wetlands harbour a large number of threatened birds, in addition to a variety of wildlife and are vital to their conservation. At least $20 \%$ of the threatened bird species inhabit wetlands in the Asiatic region which is far more than the $10 \%$ of the globally threatened brids (Kumar et al. 2005). Out of 310 Indian wetland birds, 107 species are winter migrants (Kumar et al. 2005). Migratory waterfowls are one of the most remarkable components of global biodiversity (Li \& Mundkur 2004). Waterbirds are not only the most prominent groups which attract people to wetlands, but also are good bioindicators and useful models for studying a variety of environmental problems (Urfi et al. 2005).

The wetlands of South Asia are facing tremendous anthropogenic pressure, which can greatly influence the structure of the bird community (BirdLife International 2003). The loss of waterbird habitats through direct and indirect human interferences has led to a decline in several waterbird populations. Therefore, it is vital to understand the underlying causes for the decline in populations and to control these trends in order to prevent the loss of key components of the biodiversity of wetland habitats. In this study, the diversity and richness of waterbirds of two almost similar 
wetlands were analyzed, to identify the consequences of direct and indirect human interferences.

\section{STUDY AREA}

Both the study sites (Gajoldoba Beel and Domohani Beel) are perennial cut-off meanders by the left side of Teesta River in Jalpaiguri District of West Bengal, India. Gajoldoba Beel (26.763897N \& 88.597498E) with an area of about 148 ha is situated by the side of the Gajoldoba barrage and about $26 \mathrm{~km}$ upstream to Domohani Beel (26.569688N \& 88.765644E) having an area of about 52ha. The Gajoldoba Beel is managed by the state-owned Teesta Barrage Division, Odlabari, while the Domohani Beel is privately owned. The average rainfall of this region is about $3160 \mathrm{~mm}$ and the average temperature ranges from $32.8^{\circ} \mathrm{C}$ ( $\max$ ) to $6.9^{\circ} \mathrm{C}(\mathrm{min})$.

The Gajoldoba Beel is connected with the river Teesta, therefore, its water level fluctuates in synchrony with the river. The region experiences about $78 \%$ rainfall during the monsoon (June to September) and only $0.98 \%$ rainfall during winter (December to February), however, Gajoldoba Beel experiences the highest water level during the winter season because during that period most of the gates of the barrage remain closed. Domohani Beel, on the other hand, becomes connected with the river Teesta only during the period of the monsoon and the water level in this wetland fluctuates with the normal hydrological cycle of the region.

The flora of both the wetlands is typical of this region; but Domohani Beel is infested with more pollution tolerant aquatic plants. There is no floating vegetation in about $50 \%$ of the area of Gajoldoba Beel, however, all parts of Domohani Beel is infested with floating vegetation like Eichornia crassipes, Trapa natans, Wolffia arrhiza, Nymphea odorata, Nymphea pubescens, Nymphoides cristatum, Jussiaea repens, Neptunia natans, Hygrophila polysperma, etc. Prominent floating hydrophytes at Gajoldoba Beel are Nymphea odorata, Nymphoides cristatum, Spirodela polyrrhiza and few patches of Eichornia crassipes. Among suspended and submerged vegetation Ceratophyllum demersum, Utricularia flexuosa, and Hydrilla verticillata were found in both the wetlands but Vallisneria spiralis was found only at Gajoldoba.
Emergent vegetations were predominant in many parts of Gajoldoba Beel, which were not so common in most parts of Domohani Beel. The most notable emergent hydrophytes were Ammania baccifera, Cyperus corymbosus, Cyperus cephalotes, Limnophila indica, Scirpus articulatus, Potamogeton nodosus, and Potamogeton pectinatus. Typha latifolia was found only in Gajoldoba Beel but not in Domohani; similarly wetland grasses like Phragmites were common in Domohani Beel but were totally absent in Gajoldoba.

\section{METHODS}

Both the wetlands were surveyed twice a month from March 2009 to August 2010. To estimate the number of individuals of each species and to record all sorts of birds and human activities more than 200 hours were spent in each wetland from dawn to dusk.

Each wetland was divided into three zones (viz. G1, G2, G3 for Gajoldoba and D1, D2, D3 for Domohani) for convenience of study considering the physical boundaries (mainly spurs of embankment), vegetation characteristics, bird species and human activities. The presence of humans was documented separately in each zone by instantaneous sampling during the morning (at about $0730 \mathrm{hr}$ ) and afternoon (at about $1630 \mathrm{hr}$ ) when such activities touch the highest magnitude. Direct human interference was measured in terms of average number of persons present in a one-hour duration in a particular zone. Besides getting data about direct human interference from direct observations, on site queries were made to several people to learn about the types and magnitude of indirect human interference.

Major impacts of human interference in wetlands were eutrophication and conversion of land. To measure these effects, six parameters, namely, water phosphate content, percentage of floating vegetation (mostly water hyacinth), relative abundance of submerged aquatic vegetation (in terms of percentage of submerged aquatic vegetation present in a unit area of water), depth of water (average value of various records of depths measured about the center of the zone), total water covered area and heterogeneity of the zones (in terms of differential topographical and vegetation characteristics and human use; e.g. deep/ shallow/no water zones, with floating/submerged/ emergent vegetations, with cultivated/noncultivated 
areas, etc.) were recorded periodically. Also data regarding magnitude of grazing (in terms of the average number of cattle present) were collected to predict the impact of human interference.

Bird counts were done between sunrise and $1000 \mathrm{hr}$ and between $1500 \mathrm{hr}$ and sunset, using binoculars (Olympus 10×50). On each day of observations, surveys began from vantage points, from where most of the surface area and edge were visible, and bird species were identified and counted (Bibby et al. 2000). Hidden and cryptic birds were flushed by walking around the perimeter and identified. Additionally, a walk was undertaken through the emergent vegetation zone and inaccessible parts of the wetlands were accessed by boat to count all the birds seen or heard within the wetlands. Species were identified using Grimmett et al. (1998), Kazmierczak \& van Perlo (2000) and Kumar et al. (2005).

For every zone of both wetlands, nesting status of each species was determined. A species was considered nesting if its nest, eggs or young were found; and a probable nester if it displayed behaviour consistent with nesting and there were suitable nesting sites available. Status of the migratory birds was ascertained as per the available literature (Ali \& Ripley 1988; Grimmett et al. 1998; Kumar et al. 2005).

The Pearson's Correlation Coefficient $\left(r_{p}\right)$ was used for the simple relationship analyses between the variables. Data, which departed from normal distribution were logarithmically transformed. Forward stepwise multiple regression analysis was done for each period, using premonsoon (April-May), Monsoon (July-August) and Winter (DecemberJanuary), with the number of birds as dependent variable and the characteristics of the wetlands having simple significant relationship with the number of species in the wetlands as independent variables.

\section{RESULTS}

\section{Bird assemblages}

In the two wetlands, a total of 86 bird species were recorded (Appendix 1). Eighty species were recorded at Gajoldoba Beel, and 42 species were recorded at Domohani Beel. Out of the 80 species recorded at Gajoldoba, 44 species were exclusive to this wetland. Of these 44 exclusive species, 32 species (Anatidae being dominant) were winter migrants or passage migrants, one summer migrant and 11 were residents or local migrants. Out of 42 species recorded from Domohani Beel, only six species were exclusive to this wetland. Of these six species, only one (Vanellus cinereus) was a winter migrant and the remaining five were residents or local migrants. Winter migrating duck avoided Domohani Beel. During this study period only twice, for very short periods, wintering ducks (total eight in number) were found to settle at Domohani Beel. Most of the winter migrants at the Domohani Beel were shorebirds (mainly wagtails, sandpipers and plovers). The density (number per unit area) of winter migrants at Gajlodoba Beel was significantly higher than at Domohani Beel (Table 1). However, population density of resident or local migrants (in premonsoon and winter season) and nesting bird density were significantly higher at Domohani Beel. Only the resident/local migratory birds used these wetlands for breeding and other purposes during the monsoon period and their density was not significantly different (Table 1) at the two wetlands.

\section{Types and magnitude of direct human interferences}

Local people used both the wetlands for various purposes (Table 2) for their livelihood, fishing being most common activity. At Gajoldoba Beel the type

Table 1. Density (number per hectare) of birds of different status and season

\begin{tabular}{|l|l|c|c|c|c|c|c|}
\hline & Season & \multicolumn{2}{|c|}{ Gajoldoba } & \multicolumn{2}{|c|}{ Domohani } & & \\
\hline & & Mean & SD & Mean & SD & $\mathbf{t}$ & $\mathbf{p}$ \\
\hline Winter migrants & Winter & 28.2 & 3.61 & 10.8 & 1.14 & 9.16 & $<0.001$ \\
\hline Nesting birds & Monsoon & 1.89 & 0.23 & 5.69 & 2.1 & 6.16 & $<0.001$ \\
\hline \multirow{3}{*}{ Residents/local migrants } & Pre-monsoon & 7.28 & 0.87 & 35.38 & 1.86 & 27.36 & $<0.001$ \\
\cline { 2 - 8 } & Monsoon & 8.03 & 0.56 & 8.97 & 1.31 & 1.3 & $>0.05$ \\
\cline { 2 - 8 } & Winter & 6.54 & 0.32 & 17.05 & 2.14 & 9.7 & $<0.001$ \\
\hline
\end{tabular}

$\mathrm{t}$ - value of $\mathrm{t}$-test; $\mathrm{p}$ - probability value to determine statistically significant result. 
Table 2. Types and magnitude (number of persons involved per hour) of human interferences.

\begin{tabular}{|l|c|c|c|c|c|c|}
\hline Activities & \multicolumn{3}{|c|}{ Gajoldoba } & \multicolumn{3}{c|}{ Domohani } \\
\hline & PM & M & W & PM & M & W \\
\hline Fishing & 14.7 & 16.8 & 16.1 & 6.2 & 16.6 & 14.5 \\
\hline Agricultural works & 0.1 & 0.2 & 0 & 19.3 & 4.7 & 6.8 \\
\hline Collection of plants & 0.2 & 0.2 & 0.3 & 1.8 & 0.2 & 0.2 \\
\hline Hunting of birds & 0 & 0 & 0 & 0 & 0 & 0.1 \\
\hline Other activities & 0.2 & 0.2 & 2.2 & 0.7 & 0.9 & 1.1 \\
\hline
\end{tabular}

PM - Pre-monsoon, M - Monsoon, W - Winter

and magnitude of human use remained almost the same through all the seasons. At Domohani Beel also the fishing activity was high during monsoon and winter. However, during the drier parts of the year intense agricultural work (in almost $80 \%$ area) was observed. During winter, a considerable number of tourists and picnic parties visited Gajoldoba, however, the birds were indifferent to such disturbances. Hunting of birds (with indigenous weapons) was reported only twice during winter at Domohani. During January to March, most parts of the Domohani Beel are used for 'Rabi' (Boro) rice cultivation. For that purpose, the land was cleared and leveled, ridges and embankments were built up, cultivated land was flooded with the remaining wetland water, and insecticides were sprayed indiscriminately. As a result, the areas with intense agricultural activities seemed as having no vegetative or topographical heterogeneity (Fig. 1).

\section{Relationships between bird assemblages and human influenced wetland variables}

Out of eight parameters only five were significantly correlated with the number of waterbird species (Table 3). Direct human interference, grazing, and phosphorus content in the covered area and the percentage of submerged aquatic vegetation were significantly correlated with bird species numbers in all the seasons. Average depth of wetland and habitat heterogeneity were significant in the premonsoon and winter seasons but not during the monsoon period. Floating vegetation percentage was significantly correlated with waterbird species numbers only during the monsoon period.

The five significantly correlated parameters were entered in forward stepwise multiple regression analysis separately for the resident / local migratory

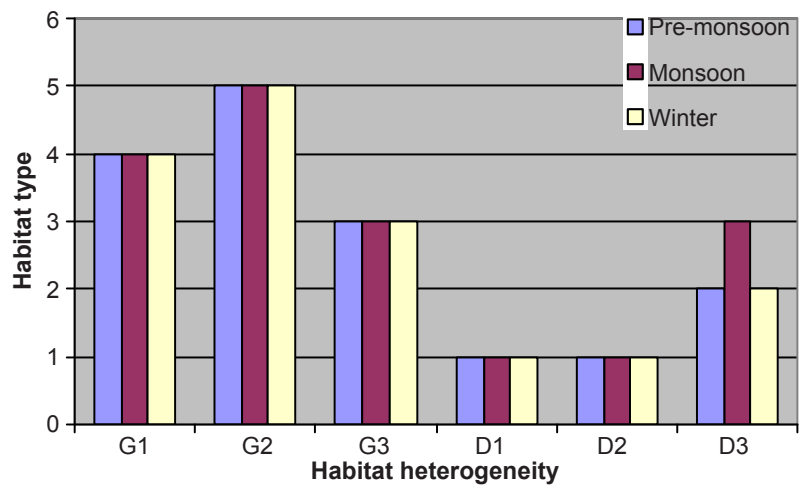

Figure 1. Degrees of habitat heterogeneity at different zones of Gajoldoba (G1, G2, G3) and Domohani (D1, D2, D3) beels at different seasons. Scale on the $Y$ axis signifies type of habitat within each zone.

birds (for all seasons), winter migrants (for winter period), and nesting birds (Table 4). In winter, the number of migratory birds was best predicted by habitat heterogeneity. Habitat heterogeneity was also the major characteristic that best predicted the wintering migratory duck assemblage. However, wintering migratory bird density was best predicted by the percentage of submerged aquatic vegetation. The number of resident or local migratory birds was best predicted by the total water covered area and also it was positively related to the presence of submerged vegetation. However, average depth of the water body and the presence of floating vegetation had a negative impact on the number of resident or local migrants through all the seasons (Table 4). The nesting bird population was best predicted by the percentage of floating vegetation covered area and the total water covered area.

\section{DISCUSSION}

Although the climatic and geophysical conditions of these two wetlands are almost identical, there is a considerable difference in waterbird diversity. Winter migrants, particularly the wintering ducks, are not attracted to Domohani Beel. However, residents and local migrants use both the wetlands with almost the same zest. As far as type and magnitude of human interferences are concerned, both the wetlands face almost similar problems during the monsoon and pre-monsoon periods. In winter, the boro cultivation, which is practised intensively only at Domohani Beel 
Table 3. Statistical relationships between wetland characteristics and number of waterbird species

\begin{tabular}{|c|c|c|c|c|c|c|}
\hline \multirow[t]{2}{*}{ Variables } & \multicolumn{2}{|c|}{ Premonsoon period } & \multicolumn{2}{|c|}{ Monsoon period } & \multicolumn{2}{|c|}{ Winter period } \\
\hline & r & $\mathrm{p}$ & r & $\mathrm{p}$ & r & $\mathrm{p}$ \\
\hline 1. Direct human interference (encounter rate) & -0.12 & n.s. & 0.4 & n.s. & -0.11 & n.s. \\
\hline 2. Coverage of water surface by floating & -0.23 & n.s. & 0.88 & $<0.001$ & -0.34 & n.s. \\
\hline \multicolumn{7}{|l|}{ Vegetation (\%) } \\
\hline 3. Average depth $(\mathrm{m})$ & 0.9 & $<0.001$ & 0.14 & n.s. & 0.82 & $<0.001$ \\
\hline 4. Submerged aquatic vegetation (\%) & -0.57 & $<0.05$ & 0.74 & $<0.01$ & -0.91 & $<0.001$ \\
\hline 5. Water covered area $(\%)$ & 0.96 & $<0.001$ & 0.82 & $<0.001$ & 0.88 & $<0.001$ \\
\hline 6. Habitat heterogeneity (number of types) & 0.93 & $<0.001$ & -0.38 & n.s. & 0.96 & $<0.001$ \\
\hline 7. Total phosphorus in water $(\mathrm{mg} / \mathrm{l})$ & -0.4 & n.s. & 0.22 & n.s. & -0.32 & n.s. \\
\hline 8. Number of cattle per hectar & -0.38 & n.s. & 0.24 & n.s. & -0.40 & n.s \\
\hline
\end{tabular}

$r$ - Pearson's correlation coefficient; $p$ - probability value to determine statistically significant result; n.s. - not significant.

Table 4. Results of the forward stepwise multiple regression test for the resident/local migrants, winter migrants and nesting birds, using the number of birds as dependent variables and the wetland characteristics significantly correlated with the number of species as independent variables. Analysis based on logarithmically transformed data of the variables $2,3,4,5$ in the Table 3. Level of significance: ${ }^{*} p \leq 0.05,{ }^{* *} p \leq 0.001,{ }^{* * *} p \leq 0.0001$.

\begin{tabular}{|c|c|c|c|c|c|c|}
\hline $\begin{array}{l}\text { Variables included } \\
\text { in the Model }\end{array}$ & $\mathbf{r}^{2}$ & Adjusted $r^{2}$ & $\mathbf{F}$ & b & $\mathbf{t}$ & $\mathbf{p}$ \\
\hline \multirow[t]{2}{*}{ Winter migrants } & & & $\mathrm{F} 1,23$ & & & \\
\hline & 0.643 & 0.627 & 39.636 & & & *** \\
\hline Habitat heterogeneity & & & & 0.802 & 6.296 & *** \\
\hline \multicolumn{7}{|l|}{ Migratory wintering ducks } \\
\hline & 0.612 & 0.594 & 34.659 & & & *** \\
\hline Habitat heterogeneity & & & & 0.782 & 5.887 & *** \\
\hline \multicolumn{7}{|l|}{ Winter migrant density } \\
\hline & 0.642 & 0.626 & 39.52 & & & *** \\
\hline Submerged aquatic vegetation (\%) & & & & -0.801 & -6.286 & *** \\
\hline \multirow[t]{2}{*}{ Residents/Local migrants } & & & $\mathrm{F} 4,53$ & & & \\
\hline & 0.788 & 0.77 & 45.475 & & & *** \\
\hline Water covered area & & & & 1.765 & 9.484 & *** \\
\hline Average depth & & & & -0.959 & -5.167 & *** \\
\hline Submerged aquatic vegetation (\%) & & & & 0.537 & 4.722 & *** \\
\hline $\begin{array}{l}\text { Floating vegetation covered } \\
\text { area }(\%)\end{array}$ & & & & -0.328 & -2.904 & ** \\
\hline \multirow[t]{2}{*}{ Nesting birds } & & & $\mathrm{F} 2,23$ & & & \\
\hline & 0.88 & 0.869 & 77.155 & & & *** \\
\hline $\begin{array}{l}\text { Floating vegetation } \\
\text { covered area }(\%)\end{array}$ & & & & 0.9 & 11.913 & *** \\
\hline Water covered area & & & & 0.27 & 3.578 & $* *$ \\
\hline
\end{tabular}

$r^{2}$ - coefficient of determination; $F$ - value of $F$ test

and not attracting any migratory duck species, opens up the scope of exploring a possible relationship between the absence of wintering ducks and 'boro' cultivation.

As the results suggest, direct human interferences do not impose any real threat to the birdlife of these two wetlands. Possibly general awareness of the people of this region and the surveillance of the Gajoldoba barrage authority have restricted people from doing 
any harm to the birds. However, intense agricultural activities have changed the wetland habitat variables at Domohani Beel and that in turn has influenced the bird life.

There exists a strong positive correlation between habitat size and species diversity that consistently corresponds with results of other studies in a variety of environments (Sillen \& Solbreck 1977; Brown \& Dinsmore 1986; Opdam 1991; Andren 1994; Turner 1996; Babbitt 2000; Paracuellos \& Telleria 2004; Gonzalez-Gajardo et al. 2009). The only other wetland characteristic, which is significantly correlated with waterbird species diversity during all the seasons, is submerged aquatic vegetation. Interestingly submerged aquatic vegetation percentage was positively correlated with avifauna diversity in the monsoon period but there exists significant negative correlation between these two parameters during winter and premonsoon periods. During the monsoon period, mostly nondiving wading and dabbling birds are found in this region and these birds prefer foraging for submerged vegetation in shallow water, even when food is in abundance in deeper water (Holm \& Clausen 2006). Wintering birds, however, preferred to forage in water with less submerged vegetation.

As expected, a number of variables were associated with the densities of waterbirds during the monsoon period. Water covered area is the most important criterion that dictates bird number positively but the average depth of the water body has a negative impact on bird numbers. Many studies have indicated that water depth affects waterbird diversity (Velasquez 1992; Elphick \& Oring 1998; Colwell \& Taft 2000; Isola et al. 2002; Darnell \& Smith 2004). Non-diving waterbirds generally prefer to forage in shallow water. As the wading and dabbling birds are the dominant waterbird groups in most regions worldwide, the greatest waterbird diversity and density generally occur at a relatively shallow water depth (Elphick \& Oring 1998, 2003; Colwell \& Taft 2000; Isola et al. 2002; Taft et al. 2002). Foraging in shallow water is also beneficial in terms of higher net energy intake (Kushlan 1978; Guillemain \& Fritz 2002; Nolet et al. 2002; Sustainable Ecosystems Institute 2007). During the monsoon, when submerged areas are abundant, the greatest concentration of waterbirds is expected in shallow wetlands like Domohani Beel.

Only resident or local migratory birds nested in both the wetlands during the monsoon and the predominance of floating vegetation in the preferred nesting zone supports the views of many other studies that advocate the importance of floating vegetation in the breeding success of many waterbirds (Owen \& Black 1990; Froneman et al. 2001; Sánchez-Zapata et al. 2005). Plenty of water hyacinth dominated floating vegetation at Domohani Beel possibly attributes to the higher nesting density in comparison to the Gajoldoba Beel. Lower nesting density at Gajoldoba Beel may also be due to higher water level fluctuation. During the monsoon (nesting season) periodically most of the gates of the barrage remain open resulting in huge fluctuations of water level. In fact the lowest water level at Gajoldoba Beel was recorded during the monsoon period. Water level fluctuations often create "ecological traps" and are detrimental for breeding birds (Kaminski et al. 2006). Many studies have shown that the brood densities of waterbirds are greater on wetlands with stable water levels than on seasonally flooded wetlands (e.g., Ogden 1991; Connor \& Gabor 2006)

In this study habitat heterogeneity was found to be the key component to attract winter migrants and more specifically the wintering ducks. Many studies have demonstrated the importance of habitat heterogeneity in wetland bird richness and abundance (Svingen \& Anderson 1998; Edwards \& Otis 1999; Fairbairn \& Dinsmore 2001; Riffel et al. 2001; Zárate-Ovando et al. 2008; Gonzalez-Gajardo et al. 2009). At present Domohani Beel does not attract the wintering ducks possibly because of its loss of habitat heterogeneity. Intense agricultural practices during drier parts of the season make it impossible to maintain structural heterogeneity, both in terms of vegetative heterogeneity and topographical heterogeneity. Thick submerged aquatic vegetation also appeared as a deterrent factor for winter migrants. Predominance of such vegetation at Domohani Beel possibly came as an artifact of agricultural eutrophication. The runoff from agricultural land enters the wetland causing an increase in the nutrient concentrations of soil and water. The most evident results of the nutrient input are the replacement of the primary native species with hypertrophy tolerant species. This in turn alters the ecosystem considerably. Nutrient-enriched water bodies thus get choked with excessive growths of aquatic macrophytes (Roelofs 1983; Wright 2009). 
In summary, species richness and bird abundance was fundamentally affected by attributes of the size of the water covered area, particularly in case of local migrants and resident birds. Diversity and abundance of wintering migratory birds appears to be affected more by habitat heterogeneity, and preponderance of submerged aquatic vegetation played a negative role in this regard. Loss of habitat heterogeneity and predominance of submerged aquatic vegetation in turn appears to be an artifact of agricultural practices. Thus agricultural practices at Domohani Beel are supposed to be the main cause of avoidance by wintering migratory birds. However, local migrants and resident birds are still thriving and breeding successfully in both the wetlands, which indicate that the level of alteration and eutrophication borne out of agricultural practices have not impaired the birdlife totally at Domohani Beel and also it advocates the adaptability of local birds.

\section{REFERENCES}

Ali, S. \& S.D. Ripley (1988). Compact Handbook of the Birds of India and Pakistan: together with those of Bangladesh, Nepal, Bhutan, and Sri Lanka-2 $2^{\text {nd }}$ Edition. Oxford University Press, 890pp.

Andren, H. (1994). Effects of habitat fragmentation on birds and mammals in landscapes with different proportions of suitable habitat: a review. Oikos 71(3): 355-366.

Babbitt, K. (2000). Use of temporary wetlands by anurans in a hydrologically modified landscape. Wetlands 20(2): 313-322.

Bibby, C., N. Burgess, D. Hill \& S. Mustoe (2000). Bird Census Techniques. Academic Press, London, 302pp.

BirdLife International (2003). Saving Asia's Threatened Birds: A Guide for Government and Civil Society. BirdLife International, Cambridge, 246pp.

Brown, M. \& J.J. Dinsmore (1986). Implications of marsh size and isolation for marsh bird management. Journal of Wildlife Management 50(3): 392-397.

Colwell, M.A. \& O.W. Taft (2000). Waterbird communities in managed wetlands of varying water depth. Waterbirds 23(1): 45-55.

Connor, K.J. \& S. Gabor (2006). Breeding waterbird wetland habitat availability and response to water-level management in Saint John River floodplain wetlands, New Brunswick. Hydrobiologia 567: 169-181.

Darnell, T. \& E.H. Smith (2004). Avian use of natural and created salt marsh in Texas, USA. Waterbirds 27(3): 355361.

Edwards, N. \& D. Otis (1999). Avian communities and habitat relationships in South Carolina Piedmont beaver ponds.
American Midland Naturalist 141(1): 158-171.

Elphick, C.S. \& L.W. Oring (1998). Winter management of Californian rice fields for waterbirds. Journal of Applied Ecology 35(1): 95-108.

Elphick, C.S. \& L.W. Oring (2003). Conservation implications of flooding rice fields on winter waterbird communities. Agriculture, Ecosystems and Environment 94(1): 17-29.

Fairbairn, S. \& J. Dinsmore (2001). Local and landscapelevel influences of wetland bird communities of the praire pothole region of Iowa, USA. Wetlands 21(1): 41-47.

Fraser, L.H. \& P.A. Keddy (2005). The World's Largest Wetlands: Ecology and Conservation. Cambridge University Press, Cambridge, 498pp.

Froneman, A., M.J. Mangnall, R.M. Little \& T.M. Crowe (2001). Waterbird assemblages and associated habitat characteristics of farm ponds in the Western Cape, South Africa. Biodiversity and Conservation 10(2): 251-270.

Gonzalez-Gajardo, A, P.V. Sepulveda \& R. Schlatter (2009). Waterbird Assemblages and Habitat Characteristics in Wetlands: Influence of Temporal Variability on SpeciesHabitat Relationships. Waterbirds 32(2): 225-233.

Grimmett, R., C. Inskipp \& T. Inskipp (1998). Birds of the Indian Subcontinent. Oxford University Press, New Delhi, 888pp.

Guillemain, M. \& H. Fritz (2002). Temporal variation in feeding tactics: exploring the role of competition and predators in wintering dabbling ducks. Wildlife Biology 8(2): 81-90.

Holm, T.E. \& P. Clausen (2006). Effects of water level management on autumn staging waterbird and macrophyte diversity in three Danish Coastal Lagoons. Biodiversity and Conservation 15(14): 4399-4423.

Isola, C.R., M.A. Colwell, O.W. Taft \& R.J. Safran (2002). Interspecific differences in habitat use of shorebirds and waterfowl foraging in managed wetlands of California's San Joaquin Valley. Waterbirds 25(suppl. 2): 196-203.

Kaminski, M.R., G.A. Baldassarre \& A.T. Pearse (2006). Waterbird responses to hydrological management ofWetlands Reserve Program habitats in New York. Wildlife Society Bulletin 34(4): 921-926.

Kazmierczak, K. \& B. van Perlo (2000). A Field-Guide to the Birds of India, Sri Lanka, Pakistan, Nepal, Bhutan, Bangladesh and the Maldives. Om Book Service, New Delhi, India, 352pp.

Kumar, A., J.P. Sati, P.C. Tak \& J.R.B. Alfred (2005). Handbook on Indian Wetland Birds and their Conservation. Zoological Survey of India, Kolkata, India, xxvi+468pp.

Kushlan, J.A. (1978). Feeding ecology of wading birds, pp. 249-298. In: Sprunt, A., J.C. Ogden \& S. Winckler (eds.). Wading birds. National Audubon Society, New York.

Li, Z.W.D. \& T. Mundkur (2004). Numbers and distribution of waterbirds and wetlands in the Asia-Pacific region. Results of the Asian Waterbird Census: 1997-2001. Wetlands Internationals, Kuala Lumpur, Malayasia.

Nolet, B.A., R.V. Bevan, M. Klaassen, O. Langevoord \& Y.G.J.T. van der Heijden (2002). Habitat switching by 
Appendix 1. List and status of birds recorded at Gajoldoba and Domohani beels.

\begin{tabular}{|c|c|c|c|c|c|c|}
\hline & Common name & Scientific name & $\begin{array}{l}\text { Found } \\
\text { at }\end{array}$ & $\begin{array}{l}\text { Residential } \\
\text { status }\end{array}$ & $\begin{array}{c}\text { Conser- } \\
\text { vation status }\end{array}$ & $\begin{array}{l}\text { Abundance } \\
\text { status }\end{array}$ \\
\hline & \multicolumn{6}{|l|}{ Waterbirds } \\
\hline 1 & Little Grebe & Tachybaptus ruficollis & B & $\mathrm{R} / \mathrm{LM}$ & & Com \\
\hline 2 & Great Crested Grebe & Podiceps cristatus & G & WM & & Ucom \\
\hline 3 & Little Cormorant & Phalacrocorax niger & $\mathrm{B}$ & R/LM & & Com \\
\hline 4 & Great Cormorant & Phalacrocorax carbo & $\mathrm{B}$ & WM & & Com \\
\hline 5 & Little Egret & Egretta garzetta & $\mathrm{B}$ & R/LM & & Com \\
\hline 6 & Median Egret & Mesophoyx intermedia & B & R/LM & & Com \\
\hline 7 & Large Egret & Casmerodius albus & B & R/LM & & Lcom \\
\hline 8 & Grey Heron & Ardea cinerea & G & WM & & Lcom \\
\hline 9 & Purple Heron & Ardea purpurea & G & R/LM & & Lcom \\
\hline 10 & Cattle Egret & Bubulcus ibis & B & $\mathrm{R} / \mathrm{AM}$ & & Com \\
\hline 11 & Indian Pond Heron & Ardeola grayii & B & $\mathrm{R} / \mathrm{LM}$ & & Com \\
\hline 12 & Black-crowned Night Heron & Nycticorax nycticorax & B & R/LM & & Lcom \\
\hline 13 & Yellow Bittern & Ixobrychus sinensis & $\mathrm{D}$ & R/LM & & Ucom \\
\hline 14 & Chestnut Bittern & Ixobrychus cinnamomeus & B & $\mathrm{R} / \mathrm{LM}$ & & Lcom \\
\hline 15 & Asian Openbill-Stork & Anastomus oscitans & B & $\mathrm{R} / \mathrm{LM}$ & & Lcom \\
\hline 16 & Black Stork & Ciconia nigra & G & WM/PM & & Ucom \\
\hline 17 & Lesser Adjutant-Stork & Leptoptilos javanicus & B & R/LM & VU & $\mathrm{Ra}$ \\
\hline 18 & Black Ibis & Pseudibis papillosa & B & $\mathrm{R}$ & $\mathrm{BRS}(11)$ & Ucom \\
\hline 19 & Lesser Whistling-Duck & Dendrocygna javanica & $\mathrm{B}$ & $\mathrm{R} / \mathrm{LM}$ & & Lcom \\
\hline 20 & Brahminy Shelduck & Tadorna ferruginea & G & WM/PM & & Lcom \\
\hline 21 & Cotton Teal & Nettapus coromandelianus & $\mathrm{B}$ & $\mathrm{R} / \mathrm{LM}$ & & Lcom \\
\hline 22 & Gadwall & Anas strepera & G & WM & & Com \\
\hline 23 & Euresian Wigeon & Anas penelope & G & WM & & Com \\
\hline 24 & Mallard & Anas platyrhynchos & G & WM & & Ucom \\
\hline 25 & Spot-billed Duck & Anas poecilorhyncha & G & R/LM & & Lcom \\
\hline 26 & Northern Shoveller & Anas clypeata & G & WM & & Com \\
\hline 27 & Northern Pintail & Anas acuta & G & WM & & Com \\
\hline 28 & Garganey & Anas querquedula & G & WM & & Com \\
\hline 29 & Common Teal & Anas crecca & G & WM & & Com \\
\hline 30 & Red-crested Pochard & Rhodonessa rufina & $\mathrm{B}$ & WM & & Lcom \\
\hline 31 & Common Pochard & Aythya ferina & G & WM & & Lcom \\
\hline 32 & Ferruginous Pochard & Aythya nyroca & G & WM & NT & Lcom \\
\hline 33 & Baer's Pochard & Aythya baeri & G & WM & VU & $\mathrm{Ra}$ \\
\hline 34 & Tufted Pochard & Aythya fuligula & G & WM & & Lcom \\
\hline 35 & Smew & Mergellus albellus & G & WM & & $\mathrm{Ra}$ \\
\hline 36 & Blue-breasted Rail & Gallirallus striatus & G & R/LM & & Ucom \\
\hline 37 & Brown Crake & Amaurornis akool & G & R/LM & & Ucom \\
\hline 38 & White-breasted Waterhen & Amaurornis phoenicurus & $\mathrm{B}$ & $\mathrm{R}$ & & Com \\
\hline 39 & Common Moorhen & Gallinula chloropus & B & R/WM & & Com \\
\hline 40 & Watercock & Gallicrex cinerea & $\mathrm{D}$ & R/LM & & Lcom \\
\hline 41 & Bronze-winged Jacana & Metopidius indicus & $\mathrm{B}$ & $\mathrm{R}$ & & Lcom \\
\hline 42 & Greater Painted Snipe & Rostratula benghalensis & $\mathrm{D}$ & R/LM & & Lcom \\
\hline 43 & European Golden Plover & Pluvialis aspricaria & G & WM & & $\mathrm{Va}$ \\
\hline 44 & Little Ringed Plover & Charadrius dubius & G & R/WM & & Com \\
\hline
\end{tabular}




\begin{tabular}{|c|c|c|c|c|c|c|}
\hline & Common name & Scientific name & $\begin{array}{c}\text { Found } \\
\text { at }\end{array}$ & $\begin{array}{l}\text { Residential } \\
\text { status }\end{array}$ & $\begin{array}{c}\text { Conser- } \\
\text { vation status }\end{array}$ & $\begin{array}{l}\text { Abundance } \\
\text { status }\end{array}$ \\
\hline 45 & Kentish Plover & Charadrius alexandrinus & B & R/WM & & Lcom \\
\hline 46 & Northern Lapwing & Vanellus vanellus & G & WM & & Lcom \\
\hline 47 & Yellow-wattled Lapwing & Vanellus malabaricus & D & R/LM & BRS(11) & Lcom \\
\hline 48 & River Lapwing & Vanellus duvaucelii & B & R/LM & & Lcom \\
\hline 49 & Grey-headed Lapwing & Vanellus cinereus & D & WM & & Ucom \\
\hline 50 & Red-wattled Lapwing & Vanellus indicus & B & R/LM & & Com \\
\hline 51 & Common Snipe & Gallinago gallinago & B & R/WM & & Com \\
\hline 52 & Black-tailed Godwit & Limosa limosa & G & WM & & Lcom \\
\hline 53 & Common Redshank & Tringa totanus & G & R/WM & & Com \\
\hline 54 & Spotted Greenshank & Tringa guttifer & G & WM & EN & $\mathrm{Va}$ \\
\hline 55 & Green Sandpiper & Tringa ochropus & G & WM/PM & & Lcom \\
\hline 56 & Wood Sandpiper & Tringa glareola & B & WM & & Lcom \\
\hline 57 & Common Sandpiper & Actitis hypoleucos & B & R/WM & & Lcom \\
\hline 58 & Black-winged Stilt & Himantopus himantopus & G & R/LM & & Com \\
\hline 59 & Small Pratincole & Glareola lactea & B & R/LM & & Lcom \\
\hline 60 & Common Tern & Sterna hirundo & G & R/WM & & Lcom \\
\hline 61 & Whiskered Tern & Chlidonias hybridus & G & R/WM/PM & & Lcom \\
\hline \multirow[t]{2}{*}{62} & White-winged Black Tern & Chlidonias leucopterus & G & WM/PM & & Ucom \\
\hline & \multicolumn{6}{|l|}{ Water Associated Birds } \\
\hline 63 & Brahminy Kite & Haliastur indus & G & R/LM & & Lcom \\
\hline 64 & Pallas's Fish-Eagle & Haliaeetus leucoryphus & G & R/WM & Vu & Ra \\
\hline 65 & Greater Grey-headed Fish-Eagle & Ichthyohaga ichthyaetus & G & $\mathrm{R}$ & NT & Ucom \\
\hline 66 & Eastern Marsh Harrier & Circus spilonotus & B & WM & & Lcom \\
\hline 67 & Osprey & Pandion haliaetus & G & WM & & Ucom \\
\hline 68 & Peregrine Falcon & Falco peregrinus & G & WM & & Ucom \\
\hline 69 & Small Blue Kingfisher & Alcedo atthis & B & R/WM/SM & & Com \\
\hline 70 & White-breasted Kingfisher & Halcyon smyrnensis & B & R/LM & & Com \\
\hline 71 & Lesser Pied Kingfisher & Ceryle rudis & B & $\mathrm{R}$ & & Com \\
\hline 72 & Blue-tailed Bee-eater & Merops philippinus & B & R/WM & & Lcom \\
\hline 73 & Chestnut-headed Beeeater & Merops leschenaulti & G & $\mathrm{R}$ & & Lcom \\
\hline 74 & Sand Martin & Riparia riparia & G & R/WM & & Lcom \\
\hline 75 & Pale Martin & Riparia diluta & B & R/WM & & Lcom \\
\hline 76 & Plain Martin & Riparia paludicola & G & R/LM & & Com \\
\hline 77 & Common Swallow & Hirundo rustica & G & $\mathrm{R} / \mathrm{WM}$ & & Lcom \\
\hline 78 & Red-rumped Swallow & Hirundo dauria & G & R/SM/WM & & Lcom \\
\hline 79 & Streak-throated Swallow & Hirundo fluvicola & G & $\mathrm{R} / \mathrm{SM}$ & & Lcom \\
\hline 80 & White Wagtail & Motacilla alba & B & R/WM/PM & & Com \\
\hline 81 & Large Pied Wagtail & Motacilla maderaspatensis & G & $\mathrm{R}$ & & Lcom \\
\hline 82 & Citrine Wagtail & Motacilla citreola & B & R/AM/WM & & Lcom \\
\hline 83 & Grey Wagtail & Motacilla cinerea & B & R/AM/WM & & Lcom \\
\hline 84 & Water Pipit & Anthus spinoletta & B & WM & & Lcom \\
\hline 85 & White-tailed Stonechat & Saxicola leucura & G & R/LM & & Lcom \\
\hline 86 & Rufous-rumped Grass-Warbler & Graminicola bengalensis & D & $\mathrm{R}$ & & Lcom \\
\hline
\end{tabular}

B - Both wetlands; G - Gajoldoba beel; D - Domohani beel; R - Resident; LM - Local migrant; AM - Altitudinal migrant; PM - Passage migrant; SM - Summer migrant; WM - Winter migrant; EN - Endangered; VU - Vulnerable; NT - Near Threatened; BRS - Biome-Restricted Species; 11 - Indo-Malayan Tropical Dry Zone; Com - Common (flocks of more than 50 birds recorded regularly/seasonally in this region); Ucom - UnCommon (flocks of 10-50 birds recorded regularly/seasonally); Lcom - Locally common (flocks of more than 50 birds recorded regularly/seasonally in these wetlands); Ra - Rare (flocks of 5-20 birds recorded on a few occasions); Va - Vagrant (a very rare or vagrant species encountered only once during this study period and also recorded from India on only a few occasions). 
Bewick's swans: maximization of average long-term energy gain? Journal of Animal Ecology 71(6): 979-993.

Ogden, J.C. (1991). Nesting by wood storks in natural, altered, and artificial wetlands in central and northern Florida. Colonial Waterbirds 14(1): 39-45.

Opdam, P. (1991). Metapopulation theory and habitat fragmentation: a review of holarctic breeding bird studies. Landscape Ecology 5(2): 93-106.

Owen, M. \& J.M. Black (1990). Waterfowl ecology. Blackie and Son Ltd., Glasgow, UK. 194pp.

Paracuellos, M. \& J.L. Telleria (2004). Factors affecting the distribution of a waterbird community: the role of habitat configuration and bird abundance. Waterbirds 27(4): 446453.

Riffel, S.K., B.E. Keas \& T.M. Burton (2001). Area and habitat relationships of birds in great lakes coastal wet meadows. Wetlands 21(4): 492-507.

Roelofs, J.G.M. (1983). Impact of acidification and eutrophication on macrophyte communities in soft waters in The Netherlands I. Field observations. Aquatic Botany 17(2): 139-155.

Sánchez-Zapata, J.A., J.D. Anadón, M. Carrete, A.Giménez, J. Navarro, C. Villacorta \& F. Botella (2005). Breeding waterbirds in relation to artificial pond attributes: implications for the design of irrigation facilities. Biodiversity and Conservation 14(7):1627-1639.

Sillen, B. \& B. Solbreck (1977). Effects of area and habitat diversity on bird species richness in lakes. Ornis Scandinaviea 8(3): 185-192.
Sustainable Ecosystems Institute (2007). Everglades multispecies avian ecology and restoration review, Final Report, November 2007. Sustainable Ecosystems Institute, Portland, Oregon, 20pp.

Svingen, D.N. \& S.H. Anderson (1998). Waterfowl management on grass-sage stock ponds. Wetlands 18(1): 84-89.

Taft, O.W., M.A. Colwell, C.R. Isola \& R.J. Safran (2002). Waterbird responses to experimental drawdown: implications for multispecies management of wetland mosaics. Journal of Applied Ecology 39(6): 987-1001.

Turner, I.M. (1996). Species loss in fragments of tropical rain forest: a review of the evidence. Journal of Applied Ecology 33(2): 200-209.

Urfi, A.J., M. Sen \& T. Megnathan (2005). Counting birds in India: methodologies and trend. Current Science 89(12): 1997-2003.

Velasquez, C.R. (1992). Managing artificial saltpans as a waterbird habitat: species responses to water level manipulation. Colonial Waterbirds 15(1): 43-55.

Wright, A.L. (2009). Wetland Eutrophication: Early Warning Biogeochemical Indicators. SL 304, one of a series of the Soil and Water Science Department, Florida Cooperative Extension Service, Institute of Food and Agricultural Sciences, University of Florida, Gainesville, 3pp.

Zárate-Ovando, B., E. Palacios \& H. Reyes-Bonilla (2008). Community structure and association of waterbirds with spatial heterogeneity in the Bahia Magdalena-Almejas wetland complex, Baja California Sur, Mexico. Revista de Biologia Tropical 56(1): 371-389. 